\title{
Ceramics and Society in Northern Europe
}

Johannes Müller and Rick Peterson

\section{Southern Scandinavia and Northern Germany}

Johannes Müller

\section{The origins of pottery in Southern Scandinavia and Northern Germany}

The earliest types of pottery in Southern Scandinavia and Northern Central Europe have different origins and histories of development. On typological grounds we are dealing both with pottery in a late Mesolithic context (late Ertebølle c. 4300 cal BC onwards) and pottery associated with Neolithic ways of life (TRB, or Funnel Beaker, societies starting c. $4100 \mathrm{cal}$ BC) (Fischer and Kristiansen 2002; Jöns et al. 2009; Klassen 2004). The relation and origin of both is a focus of debate: while Ertebølle ceramics were seen traditionally to reflect southern influences from contemporary early horticulturalists on the Nordic Mesolithic foragers, some researchers are modelling different origins for Ertebølle and TRB assemblages. Ertebølle pottery is associated with Mesolithic/Epipalaeolithic pottery traditions, stretching from central Siberia to Brittany (Jordan and Zvelebil 2009; Matiskainen 2011; Andersen 2011; Piezonka 2011). The use of pointed-bottomed vessels is known from foraging societies which integrated some domesticates and cultivates into their economy but did not change in principle their foraging identity. No pottery or other imports imply any kind of innovative southern influences on this development; rather ceramics are seen as an independent innovation. By contrast, Funnel Beaker pottery is associated with changes related to the spread of horticulture into the North European Plain, enhanced by the expansion of an enclosure building society from the west (early Michelsberg of the Paris Basin and the Rhinelands) and late Lengyel developments within south-eastern horticultural communities (e.g., Gatersleben groups of the Middle-Elbe-Saale region). Funnel Beaker ceramic assemblages are seen as a result of the inter-linkage of Michelsberg, Late Lengyel and late Ertebølle (Fig. 1) at the southern fringe of later Funnel Beaker distribution (Klassen 2004; Müller 2011a).

Fig. 1 The interaction spheres of early Funnel Beaker Societies (after Müller 2011, 295 Fig. 7) (graphic: Holger Dieterich, Kiel).

Investigating the origins of pottery in the southern Scandinavian Neolithic often involves questioning the ideological differences between foragers and early horticulturalists: is there a clear separation of forager diets from horticultural diets, from routinely eating fish to scarcely using marine resources? The model of an evolution of early Neolithic pottery shapes out of late Mesolithic pottery is still open to question, for which the different use of ceramics in different societal spheres could be taken into consideration.

\section{Regional and Chronological Frameworks}

Since early discussions on the absolute dating of the southern Scandinavian and northern German Neolithic (Hoika 1994), the resolution of chronologies has improved rapidly (Müller et al. 2010). While twenty years ago different regions were still treated as one, recent studies confirm quite different regional shifts in the introduction of new ways of life, and especially of new pottery styles (compare Lübke and Terberger 2005 with Koch 1998). Using ceramic decoration and shapes as proxies for chronological change has resulted in a regional chronological framework for ceramics (Fig. 2). While spatially bounded and chronologically 
restricted regional ceramic groups are indicated by shapes, techniques and ornamentation (Andersen 1997; Andersson et al. 2004; Ebbesen 1975; 1978; Hartz and Lübke 2004; Hoika 1987; Hulthen 1977; Koch 1998; Madsen 1994; Malmer 2002; Meurers-Balke and Weninger 1994; Nielsen 1994; Persson 1999). General trends in decoration ratios or quantities of vessel shapes are linked to social frameworks of the Funnel Beaker (TRB) North-Group.

Fig. 2 Schematic chronological table of Funnel Beaker and Single Grave development in South Scandinavia, the Northern European Plain and the Northern Lower Mountain Range (from Müller et al. 2010 fig. 1) (graphic: Ines Reese, Kiel).

\section{Early Neolithic (EN 4100-3500 cal BC)}

The earliest Neolithic pottery (Fig. 3) in northern Germany and southern Scandinavia is divided into different regional groups of TRB-style ceramics (Early Neolithic Ia):

- Wangels/Flintbek (southern Jutland and northeastern Germany, c. 4100-3800 cal BC), mostly undecorated simple funnel beakers and plates with some stitched or arcadiac rim decoration or applied moulding below the rim;

- Volling group (northern and middle Jutland, c. 3900-3800 cal BC), decorated with stab-and-drag stitches and other horizontal fields of lines on the rim and funnel beakers of Type B;

- Svalekint group (Zealand and Scania, ca. 3950-3800 cal BC), with more stitches than in Volling but otherwise similar.

The most significant differences between these three groups are in shape and ornamentation. While the southernmost ceramics of the TRB-North Group is more or less undecorated, flat based, and with some similarities to late Mesolithic ceramics (e.g. lamps), the northernmost ceramics are sometimes highly decorated with complex patterns, possibly derived from Scanian Ertebølle communities. However, Volling pots are round-based and the body has a globular shape, which is similar to western European pottery in the Northern France and Belgium (Klassen 2004, 189-203). Typologically, Volling pottery has at least some "alien" types of decoration and pot shapes which might be comparable with western Chasséen and Early Michelsberg pottery. Such connections are probably also represented in point-necked adzes, which are the earliest adzes of TRB in Northern Europe. Beside these considerations a south/north trend in the distribution of TRB pottery is visible with it appearing in northern Germany at c. $4100 \mathrm{cal}$ BC, one to two hundred years earlier than in southern Scandinavia. These societies were characterized by small hamlets and temporary camps.

Around $3800 \mathrm{cal} \mathrm{BC}$ the constitution of these societies gradually changed with the construction of non-megalithic long barrows and the appearance of new pottery types (Early Neolithic Ib):

- The Oxie group (concentrated in Zealand and Scania, but also a few sites in Jutland, c. 3800-3500 cal BC), without over-all ornamentation, but sometimes with rim decorations like stitches on the outer rim. This assemblage of generally flat-based funnel beakers includes amphorae, flasks and spoons. While necks are usually not decorated, rims are ornamented with typical horizontal rows of short vertical lines or impressions (Madsen 1994, 231), and applications of simple stitches and nailimpressions on horizontal moulds are also known.

- The Siggeneben Süd/Stengade II group (northern Germany and Danish Isles, c. 38003600 cal BC) consists mostly of undecorated pots: funnel beakers with clearly distinguishable imported four-lugged amphorae from southern areas, and collared 
flasks. The slightly later Satrup group of northern Germany consists mainly of beakers and lugged beakers with vertical stripes on the belly.

The symbolic implications of a shift from highly decorated Early Neolithic Ia pottery to mostly undecorated Early Neolithic Ib pots has yet to be considered. The Early Neolithic II pottery (ca. 3500-3300 cal BC), associated not only with domestic structures or non-earthen long barrows, but also with causewayed enclosures and the first megaliths, begins a new intensity of decoration which continues into the Middle Neolithic (Fig. 3):

- Fuchsberg pottery in (northern Germany, most parts of Jutland, and the western Danish Isles) is characterized by flasks with elongated necks, funnel beakers with cylindric to conical rims, and bowls which are in many cases completely ornamented with geometrical patterns (bands of chevrons, ladder-like vertical patterns, vertical stripes and plastic mouldings). Collared flasks are now highly elaborated and clay plates also decorated. Wolkenwehe 1 is a southern subgroup of Fuchsberg.

- The Virum group (Scania and Zealand, c. 3600-3400 cal BC) is characterized by funnel beakers with vertical stripes on the shoulder, lugged beakers, and lugged collared beakers (Ösenkranzflaschen).

Fig. 3 Early Neolithic pottery. The differences between EN Ia, Ib and EN II phases and different style groups are indicated (after Grohmann 2010; Schwabedissen 1979; Midgley 1992) (graphic: Ines Reese, Kiel).

Middle Neolithic (MN 3300-2800 cal BC)

Middle Neolithic pottery (Fig. 4) coincides with the erection of megaliths (until c. $3100 \mathrm{cal}$ $\mathrm{BC}$ ) with its later forms giving way to Early Corded Ware design:

- The MN Ia (c. 3300-3200 cal BC) is represented by Troldebjerg and Wolkenwehe 2 styles (domestic sites in Denmark and Schleswig-Holstein) Like Fuchsberg pots, they are often completely ornamented with ladders and bands of chevrons. Funnel Beakers possess an extraordinary conical rim and drums are known for the first time.

- MN Ib (c. 3200-3100 cal BC), named after the domestic sites of Klintebakke and Wolkenwehe 2, display similar shapes, but with more elaborate ornamentation with complex arrangements of bands, lines and metopic patterns. Furthermore, the first three-limbed pots appear.

- MN II (c. 3100-3000 cal BC), named after the domestic sites of Blandebjerg and Oldenburg, is represented by three-limbed cups and jars, pedestalled bowls, and decorated clay discs. Ornamentation is fine, but not as dense as with MN I.

- These tendencies continue in MN III and MN IV (Bundsö and Lindo in Southern Scandinavia and Bostholm in northern Germany, c. 3000-2900 cal BC). Decoration is simpler, mainly consisting of triangles or simple chevron stitches. Some pots are twolimbed rather than three-limbed. .

- The MN V (Store Valby, c. 2900-2800 cal BC) is more or less equally distributed across the whole area. The ceramics are undecorated thick-walled barrel-like pots with only a few plastic applications, and simple conical beakers.

While Early Neolithic pottery indicates the regionalization of ceramic traditions over many centuries, Middle Neolithic pottery reflects an intensification in ornamentation and thus a will to representation. Obviously, the production of new and more decorative signs on pots, and probably also on other material culture, is a reflection of higher tension within and between the communities. The growing importance of local and regional identities is due to a rise of 
social differences, which enhances representative designs. Design of ornamentation and shapes comes to a quantitative and qualitative peak around $3100 \mathrm{cal} \mathrm{BC}$ when megalith construction ends (Klatt 2009). Afterwards a diversification of ceramic styles and a reduction in design variability is detectable again, ending in a period of coarse and "ugly" ceramic.

Fig. 4 Middle Neolithic pottery (after Schwabedissen 1979; Midgley 1992; Ebbesen 1975 and 1978; Madsen 1998) (graphic: Ines Reese, Kiel).

\section{Younger Neolithic (YN, 2800-2200 cal BC)}

With the appearance of Single Grave Culture (SGC) in Southern Scandinavia and Northern Central Europe marked changes in pottery design are visible (Hübner 2005). After the $29^{\text {th }}$ century BC the characteristic elements of material culture are flat-bottomed beakers with corded decoration, a significant new type without any typological link to late Funnel Beaker pots. Ceramics express a new social order despite the probability that the shift in material culture and burial rites is a result of autonomous changes, which used foreign innovations as a part of new designs. However, over the next six centuries further changes are detectable (Fig. 5):

- In the YN 1 (c. 2850-2600 cal BC) short decorated corded beakers with neck ornamentation and beakers with fishbone like decoration are part of single grave furniture. Amphorae with vertically stripped bellies (Strichbündelamphoren) and wavy-moulded ceramics (Wellenleistenkeramik), as well as finger dotted pots, are typical at domestic sites.

- In the YN 2 (c. 2600-2450 cal BC) S-profiled beakers with stroke ornaments and zone decoration are known beside footed-basins and tulip-like pots.

- YN 3 (2450-2250 cal BC) burial ceramics consist of straight-walled or slightly inwardly curved beakers. Furthermore, beakers with zone or "total" (over-all) decoration are an addition to earliest Bell Beakers and "footed basins". On domestic sites a shift from applied waved moulding to straight moulding is visible.

Fig. 5 Younger and Late Neolithic pottery (after Hübner 2005; Kühn 1979; Sarauw 2008) (graphic: Ines Reese, Kiel).

Late Neolithic (LN, c. 2200-1700 cal BC)

The LN represents a continuation of Single Grave societies (Vandkilde 1996; Apel 2001): beside the dagger replacing the axe in some male graves reflecting a general supra-regional pattern of change all other changes in material culture could be explained as a shifting construction of material culture based on the Younger Neolithic. In the Late Neolithic 1 (2200-2000 cal BC), however, Bell Beakers play an important role in both domestic and burial sites of Denmark and northern Germany (Sarauw 2008). All-Over-OrnamentedBeakers, Grooved Beakers, and developed Bell Beakers are found beside undecorated beakers and bowls. In LN 2 (2000-1700 cal BC) the numbers of Bell Beaker decreases as does the role of ceramics in burial contexts decreases. Undecorated beakers and bowls now prevail (Fig. 5).

\section{Complexity and diversity}

Beside TRB pottery in Southeastern, Middle and Northern Sweden Pitted Ware pottery is of significant importance (GRK - Swedish Gropkeramisk Kultur or PWC Pitted Ware Culture). Pitted Ware is associated with sites, dating from 3500-2200 BC and which belong to sedentary foragers with farming influences (Larsson 2009; Larsson 2006). The pottery types are quite distinct from TRB or SGC, and belong to a quite different world of burials, deposition places and domestic sites. 


\section{Summary}

More than 2000 years of Neolithic pottery in Southern Scandinavia and Northern Central Europe saw many changes in the function and use of pots with clear differences between the Early Neolithic I (4100-3500 cal BC), Early Neolithic II (3500-3300 cal BC), Middle Neolithic (3300-2800 cal BC), Younger Neolithic (2800-2200 cal BC), and Late Neolithic (2200-1700 cal BC). Differences between cultural contexts clearly demonstrate the functional and semiotic use of pots as a means of communication. They play one part in the link of material culture in relation to producers and consumers. The creative, but also normative sign system on pots express the local and regional identities both on utilitarian as well as nonutilitarian objects. Producing such patterns on a household level links economic and ideological efforts of producing and consuming parts of these Neolithic societies (Müller 2010; Müller 2011b).

\section{The social and cultural dimensions of Continental Northern European Neolithic pottery} Production

Although the technology of production has been extensively studied (e.g. Hulthen 1977; Koch 1998), no sites of production and firing have yet been discovered. It is assumed that Southern Scandinavian pottery was produced as a local, home-made ceramic with different techniques of building up the pots. There are no visible differences between coarse and fine ceramics and the spectra of technological shifts, e.g., the use of temper, the temperature of firing and the work on ceramic surfaces. In consequence, differences or similarities in ceramic design may indicate the relational habitus shared by or distinguishing social units as households or small groups producing pottery.

\section{Distribution}

Neolithic ceramics were produced locally - no evidence has been found for any regional or supra-regional exchange. In consequence, similarities in shape and ornamentation result from functional similarities and shared culturally-defined sign systems. Thus, distribution patterns indicate the strength of communication between people rather than the exchange of ceramics as commodities. In this respect Neolithic ceramics in the Northern European Plain and southern Scandinavia are a useful proxy for identifying spatial communication patterns and dense communication spaces (fig. 6).

Fig. 6 Spatial communication patterns indicated by ceramic design. The results of a network analyses of different TRB regions indicate similarities and distances between these groups (after Furholt in print).

\section{Consumption}

The reconstruction of consumptive patterns is based not only on the reconstruction of ceramic design but also on depositional processes, which are associated with different categories of archaeological sites at different times. While evidence from the Late Neolithic is too scarce to come up with conclusions about consumption practices, much more can be said about the TRB and SGC periods.

During the TRB it is possible to reconstruct patterns of household and burial deposition which suggest ceramic types were often specially selected for specific purposes in certain quantities. More or less all known ceramic shapes and ornaments occur at houses or small hamlets: coarse ware is used for cooking and storing, while middle fine and fine ceramics are used decoratively for communication during eating. During the Early Neolithic Ia there was no clear differentiation in the use of decorative patterns or pot shapes between graves and 
domestic sites. The same is true for the Early Neolithic II, where domestic sites, causewayed enclosures, and burials again have similar decoration and pottery shapes within their assemblages. In contrast, during the Middle Neolithic both domestic sites and reused causewayed enclosures produce similar ceramic types, but single burials yield mostly undecorated pottery, while deposits and offerings in front of megaliths are carried out with highly decorated pots. Decorative differences probably reflect different spheres of activity, partly also displayed in the coarse/fine ware contrast.

Alongside differences in the composition of ceramic assemblages, different depositional processes are also evident during the TRB. While on domestic sites habitation debris usually includes most parts of the broken pots, the deposition of pots at both burials and causewayed enclosures often follows a pattern of deliberate destruction. A funnel beaker was broken in the gateway of an enclosure at Albersdorf-Diesknöll and the sherds then deposited in both ditch terminals (Müller 2011b). In front of many Scandinavian passage graves numerous pots were broken and deposited over many generations (Fig. 7) (Tilley 1996). At causewayed enclosures often only one quarter of the original pot was deposited (what happened to the remainder?) and they produce a relatively low density of ceramics compared to domestic sites. Obviously acts of consumption, which took place here were periodic and limited to co-operative feasting activities. Causewayed enclosures are the only archaeological remain, which indicate communal activities of the scattered hamlets depending e.g. on endogamic practices of cooperation.

Fig. 7 Ceramic deposition in front of a megalith. The "Trollasten" dolmen in Scania near Ystad. The circles indicate the number of sherds within each square meter (after Strömberg 1968, fig. 85).

Increased mobility characterises the shift from the TRB to the SGC. Clear differences are visible between SGC burial and domestic sites: wavy moulded ceramics or later straight moulded ceramics with straight pots are restricted to settlements only (Müller et al. 2009). This kind of pottery ornamentation was excluded from burial sites, perhaps as a result of different consumption practices in the funerary sphere compared to daily life.

\section{Pottery and social change}

Changes in pottery design can be linked to on-going processes by which identities were distinguished at local and regional levels among Continental Northern European Neolithic societies. The construction and use of ceramics was a key feature of the habitus of people from different groups. Thus, around $4100 \mathrm{cal}$ BC TRB pottery design reflects the new shared ideology of the small farming communities, while during the erection of the first monuments the patterns in pottery suggest new local and regional identities (Müller 2011b). The intensification of ceramic production and the increasing variation in ceramic ornamentation (starting with the first construction of megaliths and enclosures) at this time marks a new dynamic lasting for about 300 years: a dynamic in which special pots played an active role in communication between individuals and groups in both profane and ritual situations. Later, as these ceramic designs became more localised, monument construction ceased. During this period, when there was also decreased ceramic production and a move away from decoration, a new style of pottery, the corded beaker, accompanied further ideological change. For the first time the intensification of ceramic ornamentation goes hand in hand with increasing regionalisation, resulting in diverse late Single Graves Culture groups. This period is again followed by a time in which not much effort was put into ceramics which probably did not play an important role in the link between material culture and social groups. Variations in 
decoration and shape therefore seem to go hand in hand with social developments as seen through other media.

\section{Great Britain and Ireland}

Rick Peterson

\section{The origins of pottery in Britain and Ireland}

Pottery in Ireland and Britain is a late phenomenon by continental European standards. In common with other cultural traits associated with the Neolithic period there is no convincing evidence for pottery production and use before around $4000 \mathrm{cal} \mathrm{BC}$ (see below). This is not the place to consider the mechanisms by which Neolithic practices reached the islands, there being a lively and ongoing debate on the subject (Thomas 1988; Armit and Findlayson 1992; Thomas 1999; Thomas 2003; Sheridan 2003; Sheridan 2004). In the specific case of Neolithic ceramics, a degree of contact with pottery using communities elsewhere must be assumed; however, unambiguous and well-dated precursors for British and Irish material have been difficult to trace (Cleal 2004, 183; Louwe-Kooijmans 2005). Another focus of debate has been how the knowledge of pottery making and use can be transmitted. Cleal $(2004,185)$ suggested that individual mentoring and tuition was the most plausible mechanism for transmitting craft knowledge in small scale societies. The question of what individual traditions and practices made up the work of the Neolithic potter will form the core of this contribution.

\section{Figure 8: Find spots for pottery assemblages discussed in this section}

\section{Regional and Chronological Frameworks}

Since Ian Kinnes' (1988) work on the beginning of the Neolithic and Herne's (1988) work on the reliability of dates associated with the first Neolithic pottery it is now clear that none of the material from Britain or Ireland should be dated before c. 4000 cal BC. Similar studies over the last 20 years have helped refine and focus the chronology of pottery manufacture and use throughout the Neolithic (Gibson and Kinnes 1997; Cleal and MacSween 1999; Cowie 1993; Sheridan 1995; Sheridan 1997; Peterson 2003; Cleal 2004). Obviously these chronologies are regionally specific but broader trends and changes can be identified. In particular, Cleal $(2004,180-181)$ has set out the aim of developing a 'ceramic-friendly' chronology for the Neolithic. In this section a synthesis of recent work on these chronologies has been attempted to create a fourfold chronology for Ireland and Britain as a whole.

\section{First Neolithic}

In his highly influential 1988 paper Andrew Herne refined Smith's (1974) Grimston/Lyles Hill series to define the open carinated bowl as a highly unitary style of pottery belonging right at the beginning of the Neolithic. Although pottery of this style clearly is early at many sites, Cleal (2004) has questioned whether it is quite as unitary a phenomenon as Herne suggests. She identifies securely dated early assemblages which include a wider range of forms (Cleal 2004, 178-80). Similarly, although Sheridan (1995 and 1997) has identified a clear horizon of open carinated bowls as the first Neolithic pottery in both Ireland and western Scotland, she also points to examples of a more varied repertoire of shapes from sites with early dates (Sheridan 1995, 17: 1997, 218-9). The debate is largely about how much variation to allow within the overall category of the open-profiled carinated bowl. Despite these reservations, the broader idea that early pottery in Ireland and Britain tends to be in one of a small range of restricted forms still seems to be useful. Dates for this first part of the Neolithic have been variously suggested as 3950-3800 cal BC for Irish pottery (Sheridan 1995, 17), 4000-3800 cal BC for Wales (Peterson 2003, 133), 4100-3850 cal BC for southern and 
western England (Cleal 2004, 181), and more generally that this material belongs to the two centuries after 4000 cal BC (e.g. Sheridan 1997, 219; Cowie 1993, 19).

\section{Early Neolithic}

All these studies also identify material from the Early Neolithic which falls outside the very earliest phases and which can be variously considered as 'modified' or 'developed' variants of the bowl tradition. Herne $(1988,15)$ distinguished the less open carinated forms with more complex rims from sites such as Broome Heath as 'shouldered bowls' forming a distinct and slightly later tradition to his open carinated bowl pottery. A consensus is emerging that the chronological division between a first and early Neolithic is valid, at least for pottery. Cleal (2004, 181-2) further sub-divides the period in southern England into two phases - 'Early or Developing Neolithic', c. 3850-3650 cal BC, and 'High or Developed Neolithic', c. 36503350 cal BC. In eastern and central Scotland, Cowie $(1993,19)$ points to the development of his class of 'heavy bowls' alongside early decorated pottery in the mid to late $4^{\text {th }}$ millennium cal BC. Further west, recent studies by Sheridan (2000 and 2003, figures 2.4 and 2.5) include a series of early Neolithic developments in both Ireland and Western Scotland dating between 3750 and $3500 \mathrm{cal} \mathrm{BC}$. A similar Early Neolithic phase, c. 3800 to $3400 \mathrm{cal} \mathrm{BC}$, has been suggested for Welsh pottery (Peterson 2003, 133).

\section{Middle Neolithic}

In Ireland ceramics are marked by a series of regional sub-styles and modified forms developing after 3600 cal BC (Sheridan 1995, 18). In Britain the important transition is the development of the broad Impressed Ware tradition, incorporating the Ebbsfleet, Mortlake and Fengate Peterborough sub-styles of the south and east with other regional groupings further north. Since the review of radiocarbon dates by Gibson and Kinnes (1997) it is clear that the Peterborough styles at least begin around $3400 \mathrm{cal} \mathrm{BC}$ and that there is no chronological significance to the sub-styles. Similar conclusions were reached for Welsh Peterborough Ware by Gibson (1995, 30), with all pottery dating 3500-2500 cal BC. In central and eastern Scotland Impressed Ware dates tend to cluster in the earlier part of the third millennium (Cowie 1993, 21). In the west of Scotland Sheridan (2000) has suggested dates between 3500 and 3000 cal BC for Hebridean Wares, with Orcadian Unstan Bowls and the Collared Bowls of the south-west belonging between 3500 and $3250 \mathrm{cal}$ BC.

\section{Late Neolithic}

The Late Neolithic is dated by the introduction of Grooved Ware. This did not take place at the same time in all parts of Britain and Ireland and the relative importance of Grooved Ware assemblages varies from region to region. Key work on the dating of British Grooved Ware by Brindley (1999b) and Garwood (1999) puts the style as a whole between 2900 and 2100 cal BC. It is also now clear that Grooved Ware has its origins in northern Scotland (Garwood 1999, 146), probably deriving from the middle Neolithic Unstan Ware of the Orkney Islands. Grooved Ware in Ireland has only been identified relatively recently (Brindley 1999a); here it is a relatively rare component alongside the continued use of modified bowl pottery and was probably introduced around 2900-2700 cal BC.

\section{Summary}

Over the whole of Ireland and Britain it would seem sensible to discuss pottery developments using the following four phase framework: First Neolithic 4000-3800 cal BC; Early Neolithic 3800-3500 cal BC; Middle Neolithic 3500-2900 cal BC and Late Neolithic 2900-2400 cal BC. Although these phases are averages of regionally specific events and changes they should give a dated structure for major changes in the way people made and used pottery. The 
following two sections discuss the surviving evidence for the manufacture and use of pottery using this chronology.

\section{Practice and Materiality}

Pottery, like all artefacts, arises out of the application of knowledge and decisions. We recognise and reify the results of these decisions as our named styles of pottery but it is likely that categories of practice and material engagement in the prehistoric past were both more fluid and less conscious than this. The following section reviews the evidence looking primarily at how people worked with clay and used pottery.

Unfortunately, clay is such a plastic material that unambiguous traces of specific practices can often be obscured. This has particular relevance for debates about the transmission of pottery making knowledge. Attempts have been made in lithic studies to identify assemblages characteristic of the process of learning knapping (Finlay 1997; Pigeot 1990). Nothing similar can be attempted with ceramic assemblages. If pottery seems to us 'crude', 'experimental' or 'unskilled' we must remember that it was nonetheless chosen for firing and use in the Neolithic: the place for unsuccessful experiments would have been the reclaim bin - or at least its prehistoric equivalent - rather than any context which might preserve them for our study. Similarly, we should not be surprised at a high degree of technical competence in the earliest surviving pottery.

There is extensive ethnographic literature describing how pottery has been made and used in traditional societies around the world (e.g., Van der Leeuw and Pritchard 1984; Rice 1987). Taken in conjunction with detailed technical analysis of Neolithic ceramics (e.g. Darvill 1984; Jones 1999), it is possible to use this to suggest traditions of manufacture and use and to try and ascribe dates to them.

\section{Clay and Inclusions}

A source of workable clay is a fundamental requirement for all potters. Ethnographic surveys (Arnold 1981, 35) suggest that most modern potters seek clay within a single day's travel of the production site, although Rice $(1987,117)$ points to a much wider variety of practices. Depending on the geochemical properties of the source the clay may then need to be modified by processes such as levigation (mixing clay with water to allow impurities to settle out), souring (storing wet clay to allow water permeation and bacterial action to increase the plasticity), wedging (kneeding the clay to homogenize it and remove air pockets) and mixing with other clays.

Many modern potters add inert material (temper) to their clay (see Rice 1987, 118-124 for a survey of varying examples). This tends to have two functions: it aids the firing of the clay, promoting a variety of chemical reactions during the firing process (see Rice 1987, 93-98 for a summary) and greatly increases the chance of a pot surviving the firing; and depending on their properties and size, inert inclusions can modify the physical properties of the finished vessel, making it either more robust or better able to withstand the stresses of heating and cooling (see Steponaitis 1984, 85-108 for a detailed technical discussion of these effects).

All of these processes can potentially leave traces in the body of the finished pot which can be detected, particularly through the use of thin section slides (see Peacock 1970 for a review of methodologies). Historically, thin section data has tended to be used as a tool for sourcing pottery production (see Riley 1984 for a review). However, studies do exist for British Neolithic material which allow us to see the way clays and inclusions from different areas 
were chosen and blended in the same assemblage; a good example being analysis on the pottery from Trefignath chambered cairn on Anglesey (Williams and Jenkins 2005).

\section{Manufacture and Firing}

Ethnographic examples of known techniques for hand-building pottery are surveyed by Rice (1987, 124-28). Very detailed formal accounts of specific hand-building traditions are presented by Krause (1984) and Van der Leeuw (1984). It is very difficult to be sure exactly how people built pottery in the Neolithic: an expert hand potter can, if they desire, almost completely remove all traces of the processes used to form a vessel. Fortunately, some data does survive within vessel walls from most British Neolithic assemblages. This usually takes the form of voids left by the incomplete joining of one segment of the pot to another (see figure 3.1). Woods (1989, 196-200), reviewing this evidence, suggests that the dominant way of working was to build vessels from cylindrical straps of clay rather than the annular rings favoured by modern craft potters.

Figure 9: Cross-sectional views of Neolithic pottery from Blasthill chambered cairn, Argyll, showing voids and breaks in the fabric along the joins between segments.

For pottery to be any use it must be fired. No well defined Neolithic pottery production sites have yet been found, and very few assemblages have traces of production evidence such as the kneaded but unshaped clay noted from Biggar Common West, South Lanarkshire (Sheridan 1997, 202). Generally, only the data from the pottery itself tells us about firing practices. It is clear from the absence of even simple kiln-type structures that all firings were a variant on the simple bonfire and a wide range of experimental work has been carried out illustrating its effectiveness (e.g., Woods 1989).

Clays pass through two chemical changes in the temperature range we might expect for open fires: dehydration and oxidisation. Dehydration of the clay minerals occurs as they are converted from hydrous and hydrated forms of aluminium silicate to anhydrous forms. The clay looses its plasticity as the crystalline structure of the clay minerals breaks down and particles are no longer free to move against one another. Iron and carbon compounds are also present in clays as impurities. Oxidisation of the carbon compounds takes place at lower temperatures than of the iron compounds and it is the incomplete removal of this carbon which give the characteristic dark core to partially oxidized sherds (Shepard 1968, 20-21). Carbon oxidisation depends on fabric porosity, kiln atmosphere, firing temperature, firing duration, and the rate of temperature increase. The last of these can be disregarded here since open bonfires produce similarly rapid rates of temperature increase (Shepard 1968, 74-91). Fabric porosity is difficult to measure except by techniques which would be destructive to prehistoric ceramics (Shepard 1968, 127). The temperature reached during firing can be partly inferred from physical changes in clays and some inclusions, particularly if thin-section data is available (Peacock 1977, 30; Steponaitis 1984, 83; Tite 1972, 230). Kiln atmosphere and firing duration both depend on the type and amount of fuel used (Hodges 1962, 63; Rye 1981, 102; Shepard 1968, 79-84 document extensive experimental work on the effects of these choices), but also on whether or not a pit is used for the firing. Therefore, using the data available from assemblages studied in detail, it ought to be possible to make broad inferences about different firing techniques; particularly where thin section analysis has been carried out (for example the analysis by Smith and Darvill $(1990,151)$ of pottery from Hazleton North).

\section{Use}

The past uses of archaeological ceramics can be analysed through a range of well-established techniques which work best where vessels have consistently been used for similar tasks. At a 
very simple level is the recording of fire-traces on the exterior of vessels used for cooking, creating a paler and often pitted surface on the base of a pot used in this way (Fig. 3.2). It is possible to identify vessels with this secondary oxidisation and only slight sooting on the upper walls; these would have been habitually used for cooking by placing the base directly on a bed of embers. Other vessels display a different pattern of intense sooting of the base and little or no secondary oxidisation; this implies these vessels were usually suspended above the fire during cooking (Rice 1987, 235). A very high proportion of Irish and British Neolithic vessels show such traces of cooking.

Figure 10: Base and wall sherds of a complete Neolithic vessel from Blasthill, Argyll showing secondary oxidisation of the base and sooting on the walls. This vessel was placed directly on a bed of embers as a cooking pot.

Charred food remains also survive in a surprisingly high proportion of Neolithic pottery but the most successful analytical technique for studying the use of pottery has been gas chromatography of food lipids which have become chemically bonded with the clay (see Evershed et. al. 1992 for a review of methodologies). This has been used both to demonstrate consistent links between different vessel types and different foodstuffs (Jones 1999), and to document changing diets over a longer time period (Dudd and Evershed 1999). It is also possible to make broad statements about potential vessel use from the known physical characteristics of the fabric (Steponaitis 1984, 95-116). Of particular relevance are the mechanical strength of sherds and the ability of the pot to withstand thermal shock and stress. A study of this kind by the author established that these factors did not appear to limit the use of Neolithic pottery for cooking, although they may influence the kind of cooking that is possible (Peterson 2003, 151).

\section{Meaning and Associations}

The first Neolithic pottery

During the first part of the Neolithic it could be suggested that pottery production was strongly bound by rules and procedures. This can be most clearly seen in the relatively restricted range of vessel shapes and the absence of decoration in most assemblages (see Fig. 4.1). By contrast, where we have thin-section data from dated assemblages, there is a tendency for clay and inclusion 'recipes' to be complex - as at Trefignath, Anglesey, for example (Smith and Lynch 1987; Peterson 2003, 52-54). This complexity seems to be both within particular assemblages and across regions. Clay and inclusion choices are much more complicated than the minimum technical requirements to successfully fire and use pottery.

Despite the 'fine' character of much of this early pottery it appears to have been used for cooking. Although Herne $(1988,26)$ describes it as having a special character and role on the basis of his survey of British and Irish material, he also concedes that this was probably bound up with its primary function as a new technology of food preparation. Certainly large assemblages with early dates, such as from Biggar Common West, South Lanarkshire (Sheridan 1997, 204), show clear evidence of use for cooking on open fires.

Figure 11: Selected dated material belonging to the First Neolithic: a - Ballymacaldrack, Antrim (after Herity 1982); b - Biggar Common West (after Sheridan 1997); c - Gwernvale (after Britnell and Savory 1984); d-Flagstones (after Cleal 1997); e - Tankardstown South (after Sheridan 1995). 
By the later part of the Early Neolithic these clay and inclusion recipes seem to have become slightly more standardised. However, unusual tempering materials such as the burnt bone found in vessel 32 from Hazleton North, Gloucestershire (Smith and Darvill 1990, 152) also seem to belong to this period. Analysis by Smith and Darvill $(1990,151)$ of the potential and actual uses of Early Neolithic pottery from Hazleton North seems to show distinct classes of cooking and storage jars in the assemblage. In general, forms remained relatively standardised but in particular regions decorated assemblages developed (Fig. 4.2). Although Herne's (1988) model would see variability developing from a standardised 'carinated bowl' at about this date in some areas (Wales for example, see Peterson 2003, 152) the range of vessel forms actually narrows.

Figure 12: Selected dated material belonging to the Early Neolithic: a - Gwernvale (after Britnell and Savory 1984); $b$ - Hazleton North (after Smith and Darvill 1990); c - Pitnacree (after Cowie 1993); d - Windmill Hill (after Zienkiewicz and Hamilton 1999)

\section{Impressed Wares}

By the Middle Neolithic it seems as if traditions of pottery production had undergone a major change. Now the emphasis was on a wide variability in vessel form, especially in the areas outside the distribution of the Peterborough sub-styles (Fig. 4.3), allied with a profusion of new decorative techniques common to all the Impressed Ware traditions. The other major change at this date was in the inclusions used. Impressed Ware assemblages, despite the variability in form and decoration they display, tend to be tempered with locally available materials. This temper is usually processed in a very perfunctory way, leading to substantial chunks of rock inclusions such as quartz being present in much pottery of this date; see for example the large Mortlake Ware assemblage from Ogmore-by-Sea, Glamorgan (Gibson 2001).

A much more detailed understanding of the use of Middle Neolithic pottery was possible from organic residue analysis carried out at Upper Ninepence (Dudd and Evershed 1999). These vessels had clearly been used for cooking meat, primarily from cattle and sheep. Similar analysis on an Unstan ware assemblage from Stonehall, Orkney (Jones 1999, 63) demonstrated that the pottery had been used for cooking both cattle meat and milk.

Figure 13: Selected dated material belonging to the Middle Neolithic: a - Goodland (after Sheridan 1995); b - Northton, Harris (after Murphy and Simpson 2003, figure 11,4); c Ogmore-by-Sea, Glamorgan (after Gibson 2001, figure 6).

\section{Grooved Ware}

By the Late Neolithic this increasingly utilitarian approach to pottery temper seems to have been further simplified by the widespread introduction of grog tempering. We must be careful not to overstate the absence of grog in earlier periods as where we have thin-section data grog appears to be a part of even the very complex tempering strategies of the First and Early Neolithics (Darvill 2004, 194). However, by the Late Neolithic we see assemblages primarily tempered with grog or with single stone types, such as the assemblage from Links of Noltland, Orkney (Sheridan 1999, 116). Whilst vessel form and decoration shows a similarly wide range of possibilities as in the Middle Neolithic, there is much more sense of these choices being widely disseminated and understood over large areas. This is reflected in the established Grooved Ware sub-styles which cover the whole of the study area (Fig. 4.4). Organic residue studies have established a range of potential uses for Grooved Ware pottery. From Barnhouse, Orkney there is evidence for the cooking of beef, milk and barley (Jones 1999, 64), whereas at Upper Ninepence the pottery seems to have been for cooking pork 
(Dudd and Evershed 1999, 117). Charred remains and pollen within Grooved Ware at Balfarg indicate cereals, potherbs and some more exotic and potentially potent plants such as nightshades and Solanaceae (Moffat in Barclay and Russell-White 1993, 109)

Figure 14: Grooved Ware and other Late Neolithic pottery; a - Lambay Island (after Sheridan 1995); $b$ - Links of Noltland (after Sheridan 1999); c-Upper Ninepence (after Gibson 1999); $d$-Balfarg Riding School (after Barclay and Russell-White 1993)

\section{Conclusions}

In summary we can see Neolithic pottery in Ireland and Britain as a technology made up of a number of traditions and practices. The shape of vessels seems to be strongly codified in the first instance, although the range of different inclusion recipes would suggest an experimental radiation of practices. In the Middle and Later Neolithic we can suggest there was a simplification of the technical aspects of potting alongside a radiation in the range of shapes and uses that were thought appropriate.

\section{References}

Andersen, N. H. 1997. The Sarup Enclosures. The Funnel Beaker Culture of the Sarup site including two causewayed camps compared to the contemporary settlement in the area and other European enclosures. Sarup I. Jutland Archaeological Society Publications 33. Aarhus: Aarhus Universitets Forlag.

Andersen, S. 2011. Kitchen middens and the early pottery of Denmark. Bericht $R G K 89,193-$ 216.

M. Andersson, P. Karsten, B. Knarrström, M. Svensson (eds.) 2004. Stone Age Scania. Malmö: National Heritage Board.

Apel, J. 2001. Daggers of Knowledge \& Power. The Social Aspects of Flint-Dagger Technology in Scaninavia 2350-1500 cal. BC. Coast to Coast Book 3. Uppsala: Uppsala University.

Armit, I. and Findlayson, W. 1992. Hunter-gatherers transformed: the transition to agriculture in northern and western Europe. Antiquity 66, 664-676.

Arnold, D. 1981. A model for the identification of non-local ceramic distribution: a view from the present. In Howard, H. and Morris, E. (eds) Production and distribution: a ceramic viewpoint. BAR International Series 120. Oxford: BAR, 31-44.

Barclay, G. and Russell-White, C. 1993. Excavations in the ceremonial complex of the fourth to second millennium BC at Balfarg/Balbirnie, Glenrothes, Fife. Proceedings of the Society of Antiquaries of Scotland 123, 43-210.

Brindley, A. 1999a. Irish Grooved Ware. In Cleal, R. and MacSween, A. (eds) Grooved Ware in Britain and Ireland. Neolithic Studies Group seminar papers 3. Oxford: Oxbow, 23-35.

Brindley, A. 1999b. Sequence and dating in the Grooved Ware tradition. In Cleal, R. and MacSween, A. (eds) Grooved Ware in Britain and Ireland. Neolithic Studies Group seminar papers 3. Oxford: Oxbow, 133-144. 
Britnell, W. and Savory, H. 1984. Gwernvale and Penywyrlod: two Neolithic long cairns in the Black Mountains of Brecknock. Cambrian Archaeological Monographs 2. Bangor: Cambrian Archaeological Association.

Cleal, R. 1997. Earlier Prehistoric Pottery. In Smith, R., Healy, F., Allen, M., Morris, E. Barnes, I. and Woodward, P. Excavations along the route of the Dorchester by-pass, Dorset 1986-8. Wessex Archaeology Report 11. Salisbury: Wessex Archaeology, 86-102.

Cleal, R. 2004. The dating and diversity of the earliest ceramics of Wessex and south-west England. In Cleal, R. and Pollard, J. (eds) Monuments and Material Culture: papers in honour of an Avebury archaeologist: Isobel Smith. East Knoyle: Hobnob Press, 164-192.

Cleal, R. and MacSween, A. (eds) 1999. Grooved Ware in Britain and Ireland. Neolithic Studies Group seminar papers 3. Oxford: Oxbow.

Cowie, T. 1993. A survey of the Neolithic pottery of eastern and central Scotland. Proceedings of the Society of Antiquaries of Scotland 123, 13-41.

Darvill, T. 1984. A study of the Neolithic pottery fabrics from Gwernvale. In Britnell, W. and Savory, H. (eds) Gwernvale and Penywyrlod: two Neolithic long cairns in the Black Mountains. Cardiff: Cambrian Archaeological Association, 110-113.

Darvill, T. 2004. Soft-rock and organic tempering in British Neolithic pottery. In Cleal, R. and Pollard, J. (eds) Monuments and Material Culture: papers in honour of an Avebury archaeologist: Isobel Smith. East Knoyle: Hobnob Press, 193-206.

Dudd, S. And Evershed, R. 1999. The organic residue analysis of the Neolithic pottery from Upper Ninepence. In Gibson, A. The Walton Basin Project: excavation and survey in a prehistoric landscape 1993-7. CBA Research Report 118. York: Council for British Archaeology, 112-119.

Ebbesen, K. 1975. Die jüngere Trichterbecherkuiltur auf den dänischen Inseln. Arkaeologiske Stud. 2. Kopenhagen: Akademisk Forlag.

Ebbesen, K. 1978. Tragtbagerkultur i Nordjylland. Studier over Jattestuetiden. Nordiske Fortidsminder 5. Kopenhagen: Det kgl. Nord. Oldskriftesklab.

Evershed, R., Heron, C., Charters, S. and Goad, L. 1992. The survival of food residues: new methods of analysis, interpretation and application. Proceedings of the British Academy 77 , 189-208.

Finlay, N. 1997. Kid knapping: children in lithic analysis. In. Moore, J. \& Scott, E. (eds). Invisible people and processes: writing gender and childhood into European archaeology. London: Leicester University Press.

Fischer, A. and Kristiansen, K. 2002 (eds.). The Neolithisation of Denmark. 150 years of debate. Sheffield: J.R. Collis Publications.

Furholt, M. In press. Die Räumliche Struktur der entwickelten Trichterbecherkeramik: Eine quantitative Analyse stilistischer Ähnlichkeitsmuster. In M. Hinz \& J. Müller (eds..), 
Trichterbechergesellschaften: Neue Einblicke. Frühe Monumentalität und soziale Differenzierung 2. Bonn: Habelt.

Garwood, P. 1999. Grooved Ware in Southern Britain. Chronology and interpretation. In Cleal, R. and MacSween, A. (eds) Grooved Ware in Britain and Ireland. Neolithic Studies Group seminar papers 3. Oxford: Oxbow, 145-176.

Gibson, A. 1995. First Impressions: a review of Peterborough Ware from Wales. In Kinnes, I. \& Varndell, G. (eds) Unbaked Urns of Rudely Shape: essays on British and Irish pottery for Ian Longworth. Oxford: Oxbow, 23-39.

Gibson, A. 2001. Neolithic pottery from Ogmore, Glamorgan. Archaeologia Cambrensis 147 (1998), 56-67.

Gibson, A. and Kinnes, I. 1997. On the urns of a dilemma: radiocarbon and the Peterborough problem. Oxford Journal of Archaeology 16(1), 65-72.

Grohmann, I. M. 2010. Die Ertebölle- und frühtrichterbecherzeitliche Keramik aus Wangels, Kr. Ostholstein. In D. Gronenborn \& J. Petrasch (eds.), Die Neolithisierung Mitteleuropas. Mainz: Verlag RGZM) 407-22.

Hamilton, M. 1997. Pottery. In Whittle, A. Sacred Mound Holy Rings. Silbury Hill and the West Kennet palisade enclosures: a Later Neolithic complex in north Wiltshire. Oxbow Monograph 74. Oxford: Oxbow, 93-116.

Hartz, S. and Lübke, H. 2004. Zur chronostratigraphischen Gliederung der Ertebølle-Kultur und frühesten Trichterbecherkultur in der südlichen Mecklenburger Bucht.

Bodendenkmalpflege in Mecklenburg-Vorpommern 52, 119-43.

Herne, A. 1988. A time and a place for the Grimston bowl. In Barrett, J. and Kinnes, I. (eds) The archaeology of context in the Neolithic and Bronze Age: recent trends. Sheffield: John R. Collis, 9-29.

Hodges, H. 1962. Thin sections of prehistoric pottery: an empirical study. Bulletin of the Institute of Archaeology 3, 58-68.

Hoika, J. 1987. Das Mittelneolithikum zur Zeit der Trichterbecherkultur in Nordostholstein. Untersuchungen zur Archäologie und Landschaftsgeschichte. Neumünster: Wacholtz.

Hoika, J. (ed.) 1994. Beiträge zur frühneolithischen Trichterbecherkultur im westlichen Ostseegebiet : 1. Internationales Trichterbechersymposium in Schleswig vom 4. bis 7. März 1985. Untersuchungen und Materialien zur Steinzeit in Schleswig-Holstein aus dem Archèaologischen Landesmuseum der Christian-Albrechts-Universitèat 1 .

Schleswig/Neumünster: Wacholtz.

Hübner, E. 2005. Jungneolithische Gräber auf der jütischen Halbinsel. Kopenhagen: Det kgl. Nord. Oldskriftesklab.

Hulthen, B. 1977. On ceramic technology during the Scanian Neolithic and Bronze Age. Stockholm: University. 
Jones, A. 1999. The world on a plate: ceramics, food technology and cosmology in Neolithic Orkney. World Archaeology 31(1), 55-77.

Jöns, H., Lübke, H., Lüth, F. and Terberger, T. 2009. Prehistoric settlements and development of the regional economic area. Archaeological investigations along the Northeast-German Baltic Sea coast. Bericht der Römisch-Germanischen Kommission 88, 149-88.

Jordan, P. and Zvelebil, M. 2009. Ex oriente lux: the prehistory of hunter-gatherer ceramic dispersals. In Jordan, P. and Zvelebil, M. (eds.). The Dispersal of Pottery Among Prehistoric Eurasian Hunter-Gatherers, 33-90. Walnut Creek: Left Coast Press.

Kinnes, I. 1988. The cattleship Potemkin: the first Neolithic in Britain. In Barrett, J. and Kinnes, I. (eds) The archaeology of context in the Neolithic and Bronze Age: recent trends. Sheffield: John R. Collis, 2-8.

Klassen, L. 2004. Jade und Kupfer. Untersuchungen zum Neolithisierungsprozess im westlichen Ostseeraum unter besonderer Berücksichtigung der Kulturentwicklung Europas 5500-3500 BC. Aarhus: Jutland Archaeological Society.

Klatt, S. 2009. Die neolithischen Einhegungen im westlichen Ostseeraum. Forschungsstand und Forschungsperspektiven. In Terberger, T. (ed.). Neue Forschungen zum Neolithikum im Ostseeraum, 7-134. Rahden: Marie Leidorf.

Koch, E. 1998. Neolithic bog pots from Zealand, Mфn, Falster. Kopenhagen: Det kgl. Nord. Oldskriftesklab.

Krause, R.A. 1984. Modelling the making of pots: an ethnoarchaeological approach. In. Van der Leeuw, S. and Pritchard, A. (eds) The Many Dimensions of Pottery: ceramics in archaeology and anthropology. Amsterdam: Universiteit van Amsterdam, 615-699.

Kühn, H. J. 1979. Das Spätneolithikum in Schlewig-Holstein. Neumünster, Karl Wachholtz Verlag.

Larsson, A. M. 2009. Breaking and Making Bodies and Pots. Material and Ritual Practices in Sweden in the Thrid Millennium BC. Uppsala: Uppsala University.

Larrson, M. 2006. A Tale of Strange People. The Pitted Ware Culture in Southern Sweden. Lund/Kalmar: Kalmar University.

Louwe-Kooijmans. L.P. 2005. Hunters become farmers. Early Neolithic B and Middle Neolithic A. In Louwe-Kooijmans, L.P., van der Broeke, P.W., Fokkens, H. and van Gijn, A.L. (eds) The Prehistory of the Netherlands. Volume 1. Amsterdam: Universiteit van Amsterdam, 249-71.

Lübke, H. and Terberger, T. 2005. Das Endmesolithikum in Vorpommern und auf Rügen im Lichte neuer Daten. Bodendenkmalpflege in Mecklenburg-Vorpommern 52, 243-55.

Madsen, T. 1994. Die Gruppenbildung im frühesten Neolithikum Dänemarks und ihre Bedeutung. In Hoika, J. (ed.). Beiträge zur frühneolithischen Trichterbecherkultur im westlichen Ostseegebiet (Symposium Schleswig 1985). Neumünster: Wacholtz, 227-38. 
Malmer, M. P. 2002. The Neolithic of South Sweden. TRB, GRK and STR. Stockholm: The Royal Swedish Academy of Letters History and Antiquities.

Madsen, T. 1998. Die Jungsteinzeit in Südskandinavien. In J. Preuss (ed.) Das Neolithikum in Mitteleuropa. Weissbach; Beier und Beran, 423-450.

Matiskainen, H. 2011. The Adoption of Pottery in Mesolithic Finland - Sources of impulses, when and why? Bericht RGK 89, 181-92.

Meurers-Balke, J. and Weninger, B. 1994. 14C-Chronologie der frühen Trichterbecherkultur im norddeutschen Tiefland und in Südskandinavien Hoika, J. (ed.), Beiträge zur frühneolithischen Trichterbecherkultur im westlichen Ostseegebiet (Symposium Schleswig 1985), 251-87. Neumünster: Wacholtz.

Midgley, M. 1992. TRB Culture. The First Farmers on the North European Plain. Edinburgh: Edinburgh University Press.

Murphy, E. and Simpson, D. 2003. Neolithic Northton: a review of the evidence. In Armit, I., Murphy, E., Nelis, E. And Simpson, D. (eds) Neolithic Settlement in Ireland and Western Britain. Oxford: Oxbow, 101-111.

Müller, J. 2010. Ritual Cooperation and Ritual Collectivity: The Social Structure of the Middle and Younger Funnel Beaker North Group (3500 - 2800 BC). www.jungsteinsite.de (article 29.10.2010), 2010, 1-34.

Müller, J. 2011a. Early pottery in the North - a southern perspective. Bericht $R G K 89$ (2008), 287-300.

Müller, J. 2011b. Megaliths and Funnel Beakers: Societies in Change 4100-2700 BC. KroonVordaacht 13. Amsterdam: Amsterdams Archeologisch Centrum van der Universiteit van Amsterdam.

Müller, J., Seregély, T., Becker, C., Christensen, A.-M., Fuchs, M., Kroll, H., Mischka, D. and Schüssler, U. 2009. A Revision of Corded Ware Settlement Pattern - New Results from the Central European Low Mountain Range. Proceedings of Prehistoric Society 75, 125-42.

Müller, J., Brozio, J. P., Demnick, D., Dibbern, H., Fritsch, B., Furholt, M. Hage, F., Hinz, M., Lorenz, L., Mischka, D. and Rinne, C. 2010. Periodisierung der TrichterbecherGesellschaften. Ein Arbeitsentwurf. www.jungsteinsite.de (article 29.10.2010), 2010, 1-6.

Nielsen, P. O. 1994. Sigersted und Havnelev. Zwei Siedlungen der frühen Trichterbecherkultur auf Seeland. In Hoika, J. (ed.), Beiträge zur frühneolithischen Trichterbecherkultur im westlichen Ostseegebiet (Symposium Schleswig 1985). Neumünster: Wacholtz, 289-324.

Peacock, D. 1977. Ceramics in Roman and medieval archaeology. In Peacock, D. (ed) Pottery in Early Commerce: characterization and trade in Roman and later ceramics. London: Academic Press, 21-33.

Persson, P. 1999. Neolitikums början. Undersökningar kring jordbrukets introduktion $i$ Nordeuropa. Göteborg/Uppsala: University Göteborg/Uppsala. 
Peterson, R. 2003. Neolithic pottery from Wales: traditions of construction and use. BAR British Series 344. Oxford: BAR Archaeopress.

Piezonka, H. 2011. The earliest pottery east of the Baltic Sea. Bericht RGK 89, 301-46. Pigeot, N. 1990. Technical and social actors: flintknapping specialists at Magdalenian Etoilles. Archaeological Review from Cambridge 9(1): 126-141.

Rice, P. 1987. Pottery Analysis: a sourcebook. Chicago and London: University of Chicago Press.

Riley, J. 1984. Pottery analysis and the reconstruction of ancient exchange systems. In. Van der Leeuw, S. and Pritchard, A. (eds) The Many Dimensions of Pottery: ceramics in archaeology and anthropology. Amsterdam: Universiteit van Amsterdam, 55-78.

Rye, O.S. 1981. Pottery technology. Principles and reconstruction. Manuals on Archaeology 4. Washington: Taraxacum.

Sarauw, T. 2008. On the outskirts of the European Bell Beaker phenomenon. The settlement of Bejsebakken and the social organisation of Late Neolithic societies. In Dörfler, W. and Müller, J. (eds.). Umwelt - Wirtschaft - Siedlungen im dritten vorchristlichen Jahrtausend Mitteleuropas und Südskandinaviens. Offa-Beiheft 84. Kiel: Wacholtz, 83-126.

Schwabedissen, H. 1979. Der Beginn des Neolithikums im nordwestlichen Deutschland. In H. Schirnig (ed.) Großsteingräber in Niedersachsen. Hildesheim: Lax, 203-222.

Shepard, A.O. 1968. Ceramics for the Archaeologist (6 ${ }^{\text {th }}$ edn). Washington: Carnegie Institute of Washington.

Sheridan, A. 1995. Irish Neolithic pottery: the story in 1995. In Kinnes, I. \& Varndell, G. (eds) Unbaked Urns of Rudely Shape. Oxford: Oxbow, 3-21.

Sheridan, A. 1997. Pottery. In Johnston, D. (ed) Biggar Common, 1987-93: an early prehistoric funerary and domestic landscape in Clydesdale, South Lanarkshire. Proceedings of the Society of Antiquaries of Scotland 127, 202-223.

Sheridan, A. 1999. Grooved Ware from the Links of Noltland, Westray, Orkney. In Cleal, R. and MacSween, A. (eds) Grooved Ware in Britain and Ireland. Neolithic Studies Group seminar papers 3. Oxford: Oxbow, 112-124.

Sheridan, A. 2000. Achnacreebeg and its French connections: vive the 'Auld Alliance'. In Henderson, J. (ed) The prehistory and early history of Atlantic Europe. BAR International Series 861. Oxford: BAR Archaeopress, 1-15.

Sheridan, A. 2003. French Connections I: spreading the marmites thinly. In Armit, I., Murphy, E., Nelis, E. and Simpson, D. (eds) Neolithic Settlement in Ireland and Western Britain. Oxford: Oxbow, 3-17.

Sheridan, A. 2004. Neolithic connections along and across the Irish Sea. In Cummings, V. and Fowler, C. The Neolithic of the Irish Sea: materiality and traditions of practice. Oxford: Oxbow, 9-21. 
Smith, C. and Lynch, F. 1987. Trefignath and Din Dryfol: the excavation of two megalithic tombs on Anglesey. Cambrian Archaeological Monographs 3. Bangor: Cambrian Archaeological Association.

Smith, I. 1974. The Neolithic. In Renfrew, C. (ed) British Prehistory: a new outline. London: Duckworth, 100-136.

Smith, I. and Darvill, T. 1990. The prehistoric pottery. In Saville, A. Hazleton North, Gloucestershire, 1979-82: The excavation of a Neolithic long cairn of the Cotswold-Severn group. English Heritage Archaeological Report 13. London: English Heritage.

Steponaitis, V. 1984. Technological studies of prehistoric pottery from Alabama: physical properties and vessel function. In. Van der Leeuw, S. and Pritchard, A. (eds) The Many Dimensions of Pottery: ceramics in archaeology and anthropology. Amsterdam: Universiteit van Amsterdam, 81-122.

Strömberg, M. 1968. Der Dolmen Trollasten. Acta Archaeologica Ludensia 8,7.

Thomas, J. 1988. Neolithic explanations revisited: the Mesolithic-Neolithic transition in Britain and south Scandinavia. Proceedings of the Prehistoric Society 54, 59-66.

Thomas, J. 1999. Understanding the Neolithic. London: Routledge.

Thomas, J. 2003. Thoughts on the 'Repacked' Neolithic Revolution. Antiquity 77, 67-74. Tite, M.S. 1972. Methods of physical examination in archaeology. London: Seminar Press. Van der Leeuw, S.E. and Pritchard, A. 1984. (eds) The Many Dimensions of Pottery: ceramics in archaeology and anthropology. Amsterdam: Universiteit van Amsterdam.

Tilley, C. 1996. An ethnography of the neolithic: early prehistoric societies in southern Scandinavia. Cambridge: Cambridge University Press.

Van der Leuuw, S.E. 1984. Dust to dust: a transformational view of the ceramic cycle. In. Van der Leeuw, S. and Pritchard, A. (eds) The Many Dimensions of Pottery: ceramics in archaeology and anthropology. Amsterdam: Universiteit van Amsterdam, 707-774.

Vandkilde, H. 1996. From Stone to Bronze. The Metalwork of the Late Neolithic and earliest Bronze Age in Denmark. Aarhus: Jutland Archaeological Society.

Williams, J. and Jenkins, D. 2005. Petrographic analysis and classification of prehistoric pottery from northern Wales: Neolithic and Bronze Age. Studia Celtica, 38, 1-48.

Woods, A.J. 1989. Fired with enthusiasm: experimental open firings at Leicester University. In Gibson, A. (ed) Midlands Prehistory. BAR British Series 204. Oxford: British Archaeological Reports, 196-226.

Zienkiewicz, L. and Hamilton, M. 1999. Pottery. In Whittle, A., Pollard, J. and Grigson, C. The Harmony of Symbols: the Windmill Hill causewayed enclosure. Oxford: Oxbow, 257317. 